Article

\title{
The Politics of Disaster Risk Governance and Neo-Extractivism in Latin America
}

\author{
Andrés Pereira Covarrubias ${ }^{1, *}$ and Emmanuel Raju ${ }^{2,3}$ \\ ${ }^{1}$ Research Center for Integrated Disaster Risk Management (CIGIDEN), 8940000 Santiago, Chile; \\ E-Mail: andres.pereira@cigiden.cl \\ ${ }^{2}$ Department of Public Health, University of Copenhagen, 1353 Copenhagen, Denmark; E-Mail: eraju@sund.ku.dk \\ ${ }^{3}$ Copenhagen Centre for Disaster Research, University of Copenhagen, 1353 Copenhagen, Denmark \\ * Corresponding author
}

Submitted: 14 April 2020 | Accepted: 20 July 2020 | Published: 10 December 2020

\begin{abstract}
Latin America is one of the regions facing many disasters with some of the worse impacts. The current governance model has not proven successful in disaster risk reduction. This article aims to theoretically analyse the relationship between ideal regional disaster risk governance (DRG) and the actual production of disaster risk in Latin America. From the socalled 'vulnerability paradigm' and a regional standpoint, this analysis contributes to the debate with a specific focus on 'neo-extractivism.' Pointing mainly to sociopolitical processes triggered as of the early 2000s in Latin America, 'neoextractivism' relates to a regional ecological-political pattern of intensive natural resource exploitation. The first part of this article presents a regional overview of DRG and its scope in disaster risk reduction, analysing its ineffectiveness through the lens of the neoliberal governmentality problem. The second part deals with the issue of 'neo-extractivism' to outline the actual links between the political arena, the development discourse, and the creation of vulnerability and new hazards in the region's contemporary social processes. We show a correlation between political arrangements and environmental degradation that brings about both disasters and an increase in disaster risk. 'Neo-extractivism' foregrounds the political conditions for the implementation of regional DRG and reveals how its projections within the development discourse relate incongruously with the essential factors of disaster risk.
\end{abstract}

\section{Keywords}

disaster risk creation; disaster risk governance; disaster risk reduction; Latin America; natural resources; neo-extractivism; vulnerability

\section{Issue}

This article is part of the issue "The Politics of Disaster Governance" edited by Dorothea Hilhorst (Erasmus University Rotterdam, The Netherlands), Kees Boersma (Vrije Universiteit Amsterdam, The Netherlands) and Emmanuel Raju (University of Copenhagen, Denmark).

(C) 2020 by the authors; licensee Cogitatio (Lisbon, Portugal). This article is licensed under a Creative Commons Attribution 4.0 International License (CC BY).

\section{Introduction}

One of the utmost challenges in disaster studies in Latin America and the Caribbean (LAC) has been to understand the political-ecological factors underlying disasters. In studying political and critical approaches to disasters, the analytical emphasis must be placed mainly on the preconditions rather than only on the aftermath of disasters (Pelling \& Dill, 2010). Of particular concern has been to study the social construction of disasters (Alcántara-Ayala, 2019), focusing on the links between development and environment through the definition of disaster risk as a function of hazard, exposure, vulnerability, and capacity (United Nations Office for Disaster Risk Reduction, 2015a). These essential components have been understood in their reciprocal synergy, that is to say, considering their concomitance and mutual conditioning (García Acosta, 2018). 
Unlike the so-called 'physicalist model' to address disasters (Hewitt, 1983), an analysis of the complex web of relationships between society and environment that are expressed in these phenomena becomes possible with the concept of 'vulnerability' as the starting point (Hewitt, 1983; Wisner, Blaikie, Cannon, \& Davis, 1994). In LAC, an analytical model based on vulnerability has sought to point out the global dynamic underlying disasters, fairly entwined with the socio-historical processes of conquest, of coloniality and the insertion in foreign development models (García Acosta, 1996). Directly related with the critical agenda of denaturing the naturalness of disasters launched in the mid-seventies (O'Keefe, Westgate, \& Wisner, 1976), the 'vulnerability model'-known also as 'alternative model'-enabled the questioning of the very basis of what has been termed as development in LAC (González, 2015). It was no longer a matter of simply expecting answers within the development context (Cuny, 1983) but of recognising disaster risk as the product of failed development or 'mal-development' (Lavell, Gaillard, Wisner, Saunders, \& van Niekerk, 2012). It was therefore the whole economic and political system that was put under the spotlight as a vulnerability creator.

There is a common understanding that vulnerability refers basically to the predisposition to suffer damage and loss of life, livelihood, and property. However, by setting the focus on the root causes and underlying processes as a method of disaster analysis (Oliver-Smith, Alcántara-Ayala, Burton, \& Lavell, 2016), vulnerability is redefined as going beyond a typological characterisation (Wilches-Chaux, 1993) or a context of different and independent stressors (Shinbrot, Jones, Rivera-Castañeda, López-Báez, \& Ojima, 2019). More importantly, vulnerability unfolds the intertwined ecological, political, economic, and socio-cultural dimensions of disaster risk and disasters, far from its explanation as exogenous shocks.

In the light of the above, this article understands disasters and disaster risks as a result of long and slow ecological-political processes (Knowles, 2014) and forces that, on the basis of institutional decisions, nourish and boost risk drivers, intensify hazards and, ultimately, embody vulnerability and exposure patterns (Oliver-Smith et al., 2016). There are, therefore, "links between the increase and expansion of disasters and the dominant ideas, institutions, and practices" (Oliver-Smith, 2004, p. 14), which have two main implications in LAC. First, social and economic activities, interwoven with the prevailing development trends centred on economic growth, deploy against and within natural processes and create new forms of hazards giving rise to disasters (Oliver-Smith, 2004, p. 16). Second, due to unequal power relations in LAC-i.e., the 'coloniality of power' (Quijano, 2000)-risks are "unevenly distributed" (Oliver-Smith, 2017, p. 211). In other words, unequal distribution of power is a political condition in the region, the social correlative of which is differential vulnerability to disasters (Middleton \& O'Keefe, 1998).
Governance measures have become central to optimising and enhancing efforts in disaster risk reduction (DRR) and management (DRM), which reflects the priority no. 2 of the Sendai Framework for Disaster Risk Reduction (United Nations Office for Disaster Risk Reduction, 2015b). Insofar as disasters are political in their own right, then disaster risk governance (DRG) is to be understood politically as well. Hitherto Latin American governments have long recognised the need to address disaster risk, at the beginning by focusing efforts just on ex-post response and recovery. At a national level, the introduction of DRMspecific policies and instruments in recent decades has led, in fact, to a significant reduction in the number of fatalities related to extreme events (Guerrero Compeán, Salazar, \& Lacambra Ayuso, 2017). While these efforts increasingly proved to be insufficient, during the $2000 \mathrm{~s}$ governments, intergovernmental and non-governmental organisations gradually shifted the focus towards exante aspects such as vulnerability, capacity development, information, and institutional strengthening for better managing disaster reduction (World Bank, 2012). As a result, disaster prevention and risk mitigation were mainstreamed, and generated not only local and national systems of DRM, but also regional DRM cooperation (Watanabe, 2013), supported by bilateral donors and multilateral organisations-e.g., the European Commission, Spain, United Nations, the Inter-American Development Bank, and the World Bank, among others.

Moreover, formal interstate initiatives in the region have proposed to strengthen DRR strategies and increase cooperation and exchange around DRG at the regional level (United Nations Office for Disaster Risk Reduction, 2017b), while the regional level provides in fact a potential area of surplus capacity in DRR and DRM. However, so far, the governance model has not proven successful for DRR in LAC; it has been also difficult to measure risk governance or to evaluate the performance of governance systems (United Nations Office for Disaster Risk Reduction, 2017a). In any case, in LAC, DRG remains understudied, not just at a regional level but also in broader political terms.

This article contributes to an original theoretical discussion on the political conditions for DRG in LAC in the light of a regional political-ecological matrix embodied in what has been called 'neo-extractivism.' In particular, 'neo-extractivism' refers to a debate within Latin American critical thinking that emerged in the mid-2000s around a type of economic activity involving the highvolume and high-intensity removal of natural goods for export (Gudynas, 2013). Such an economic model has generated in LAC a poorly diversified productive structure highly dependent on the international market. Based on an over-exploitative use of the land and on permanent border expansion into spaces previously considered 'unproductive,' this renewed pattern has brought about disastrous effects on the environment and territories (Svampa \& Viale, 2014, p. 16), creating vulnerability and unsafe conditions. 
This article highlights that the concept of 'neoextractivism' presents new modalities of unpacking structural dynamics in the context of DRG efforts at the regional level: a deep and functional relationship between political arrangements, the development discourse, and the ecological-political processes of the social construction of disasters and disaster risk. Contemporary literature on critical disaster studies about LAC is discussed, contributing to both understanding the political scope of what is at stake in disasters and scoping regional views that enable to question underpinnings of dominant paradigms on the politics of disaster risk.

The aim in the first part of this article is to address a Latin American DRG overview by analysing it through a political lens, i.e., what the concept of governmentality implies for governance theory. A gap between DRG theory and guidelines and what is actually going on regarding disaster risk creation is unveiled, accounting for the entanglement of actors and processes which has led to vulnerability and has disclosed structural under-capacity. The second part addresses the neo-extractivism debate in order to outline the actual links between the political arena, development discourse, and the production of vulnerability and unsafe conditions by the deployment of current social processes in the region. 'Neo-extractivism' foregrounds the political conditions for the implementation of regional DRG and reveals how its projections within the discourse of development relate incongruously with essential factors of disaster risk.

\section{Latin American Disaster Risk Governance Conditions}

\subsection{Regional Overview of Disaster Risk Governance}

While governance has become central to DRR, it has also been considered a fuzzy notion with loose application (Jordan, 2008). In the world of DRM, disaster governance has been interpreted as the "interrelated sets of norms, organisational and institutional actors, and practices (spanning predisaster, transdisaster, and postdisaster periods) that are designed to reduce the impacts and losses associated with disasters" (Tierney, 2012, p. 344). This interrelation goes beyond governmental frames pointing to the collective actions through the engagement of stakeholders operating at all scales, from local to global (Gall, Cutter, \& Nguyen, 2014). A related concept of risk governance may also inform disaster governance in terms of risk-relevant decisions and actions in concrete socio-cultural contexts (Aven \& Renn, 2010). By an analytical architecture applicable either at global and local level or to their interfaces (Renn, 2008), relevant stakeholders' interests and decision-making processes at stake in disaster risk situations are evinced, disclosing power relations regarding the distribution of authority and the allocation of resources (Aysan \& Lavell, 2014).

An overview from the DRG agenda in the LAC reality shows a clear difference between the frameworks and guidelines and what is actually the case, that is to say, between 'what should be done' for governing disaster risk and the more grounded fact of 'what is actually done' (Flyvbjerg \& Richardson, 2005). Trends suggest that there are increasingly accelerated generation and accumulation of disaster risks worldwide (United Nations Office for Disaster Risk Reduction, 2015a). In relative terms, a high proportion of their impacts occurs in 'developing countries,' which are more vulnerable than developed countries. In fact, the majority of human fatalities happen in low-income or lower-middle-income countries (Rentschler, 2013), and expressed as an average percentage of GDP, the economic costs of disaster burden relatively greater on the poor (Wallemacq \& House, 2018).

According to the United Nations Office for Disaster Risk Reduction (United Nations Office for Disaster Risk Reduction, 2015b), among those affected by disasters, women, children, and people in vulnerable situations have been disproportionately affected the most. The amounts of related damages arising from disastersin infrastructure and economic assets-overburden contingency, recovery, and reconstruction budgets of Latin American states, while DRR projects are still largely dependent on international aid (Borgo, 2016). Just between 2005 and 2012, disasters in LAC caused more than 240,000 deaths, affected another 57 million people, and resulted in losses equal to US\$85 billion (United Nations Development Programme, 2014a). These numbers must be seen in relation to poverty and inequality in these societies which are manifested in various forms of vulnerability and the rising exposure to geophysical and hydrometeorological risks. More importantly, among the factors directly contributing to this vicious cycle, the following can be mentioned: the existing economic and social inequalities, the exploitation and degradation of the environment, and government systems' insufficient attention to disaster reduction (United Nations Development Programme, 2014a, pp. 2-3; Wisner et al., 1994)

In general terms, during the last few decades 'developing countries' have not advanced dramatically in an effective way to build integrated DRG mechanisms (Thompson, 2020), despite the emphasis by global frameworks and guidelines on the vital role of DRG in DRR since the 2000s. It is striking that, hitherto, a real focus on governance has not been prompted and there are only a series of piecemeal outputs-such as policies, laws, or plans-instead of complex and context-specific transformational processes (Aysan \& Lavell, 2014). Even worse, as we will discuss below, Latin American local and national governments have enormously contributed to creating unsafe conditions and greater vulnerability (Cardona, Bertoni, Gibbs, Hermelin, \& Lavell, 2010, p. 51).

Recent reports from national governments indicate that despite most of Latin American countries having signed the Sendai Framework for Disaster Risk Reduction-where strengthening DRG is a priority (United Nations Office for Disaster Risk Reduction, 
2015b) - they have not gone beyond a rhetorical recognition of what DRG is supposed to be and they have not set up DRM and DRR as state policies (Sandoval \& Sarmiento, 2019). There is also limited political will at the national levels and a lack of trust in regional organisations as independent disaster managers (Hollis, 2015, p. 143). Besides, a discourse on security, often introduced in the region as international cooperation and humanitarian aid during the 2000s, renewed the legitimacy of the 'physicalist paradigm' of disasters, bringing about a 'securitisation' of disasters (Frenkel, 2019). Inter alia this securitisation drift resulted in a reinforcement of top-down disaster responses and in the attribution of less importance to civil organisations and communities in DRM. In the end, this undermined the influence of DRG guidelines.

Efforts to DRG have been overshadowed by the effects of regional historical-structural conditions, thereby exposing a gap in the need for effective DRR strategies. Not only contemporary but also historical contexts of 'developing countries' hamper their ability to create governance systems which effectively address "the root causes of vulnerability and build capacities" (Thompson, 2020, p. 48).

It is well-known that neoliberalism has left states delivering few services, although there is still a statecentred view of governance which relies on national governments as the logical site for DRR initiatives. However, the fact that Latin American states have been diminished to a simple delivery of efficient disaster responses is not just owing to the post-sovereign shift brought about by neoliberal processes. Indeed, those states have been hollowed out since their birth as postcolonial countries in the 19th century (González Casanova, 1990). Hence, we can suggest that their chronic under-capacity and institutional weakness, which outwardly impair DRG implementation, are structural issues actively produced rather than just effects of surmountable misalignments. DRG and vulnerability in Latin American countries are "intrinsically connected through the entanglement of actors and dynamic processes that support and facilitate the production of disaster risk" (Sandoval \& Voss, 2016, p. 108). Thus, a specific analysis of this set of factors might untangle the structural dynamics behind ineffective DRG.

\subsection{Neoliberal Governance in Latin America and the Caribbean}

We suggest that an explanation for the gap between the DRG framework and aims and its "observable phenomenon" (Hufty, 2011, p. 405) can be found in the very concept of 'governance,' fairly related to the ongoing political-economic processes. By translating the core principles of 'governance' into the DRG field, the latter inevitably drags with itself the questions that burden the governance concept (Thompson, 2020). In LAC, this might be true to the extent that 'governance' - the root concept of DRG-is to be understood as anything but neutral.

The rise of the idea of 'governance' (also 'good governance') as technocratic development management relates to the reference terms prompted by institutions such as the World Bank and the IMF (Rojas \& Kindornay, 2014). Mainly directed at developing countries (Benson \& Jordan, 2017), in the late 1980s, governance became a methodological tool of the World Bank aimed at evaluating the norms and practices of states or organisations, which ended up becoming a political device for changing societies rather than an analytical approach (Hufty, 2009). It is important to remember that since the 1980s, the World Bank and the IMF became centres for the world-wide propagation and execution of the neoliberal orthodoxy (Harvey, 2005). In fact, these kinds of international and global institutions have been important actors in shaping the contours of disaster governance on a global scale, especially in developing countries (Tierney, 2012). The explicit references to the idea of 'good governance' in both the Sendai Framework for Disaster Risk Reduction and the Hyogo Framework for Action might be illustrative of that influence.

In Latin American countries, the promotion of the governance discourse legitimised the rearticulation of the relationships between the state, civil society, and the market in the neoliberal transition of the 1990s after a period of dictatorships (Bassols, 2011). During those processes, governance operated as an increasingly sophisticated and depoliticising discursive device of the hegemonic vision of development (Svampa \& Viale, 2014). Thus, it became a constituent part of the "political matrix of neoliberal globalisation" (De Sousa Santos, 2009, p. 46).

The crux of the matter is that the governance paradigm uncovers a rationality embodied in its practices; a thought within the exercise of administrative power over the population that has been known as 'governmentality' (Foucault, 2009). Governmentality has enabled deeming the 'mentality' of government that neoliberalism brought about as a new regime of governing practices and strategies. Mainly, it refers to a structural dynamic of shaping and reshaping conducts both moral and political, in practices and institutions, towards a "particular matrix of ends and purposes" (Dean, 2010, p. 32). This dynamic operates in a transnationalised manner across uneven power relations and will of dispersed entities that include states, supranational organisations, transnational corporations, NGOs, professional associations, and individuals (Fraser, 2003). Accordingly, the critique of neoliberal governance has brought a disassociation between spatial and scalar dimensions out into the open, disclosing the transnational nature of the 'state' and the 'local' (Ferguson \& Gupta, 2002).

In risk governance terms, neoliberal governmentality was first reflected in the dissolution of the idea of individuals within state care and the replacement of such idea by the management of flows of self-governed population 
in light of a combination of probabilistic and abstract risk factors (Castel, 1991). In this context, the risk itself has been privatised, individualised, and desocialised (Dean, 2010). The politics of (disaster) risk, thus, can be seen as a strategy to both identify and set in motion "local solidarities of diverse aggregations" (Dean, 2010, p. 221) and to encourage their several nexuses. This strategy is promoted by top-down initiatives through bottomup self-management processes aiming to achieve community resilience. Paradoxically, in LAC, such a strategy has not really driven the governing procedures to boost risk reduction. There is an overwhelming contradiction in DRG that remains at the regional level, which operates against DRM strategies, yielding local efforts in DRR very ambivalent.

\section{The 'Blind Spot' of Disaster Risk Governance in Latin America and the Caribbean: Neo-Extractivism}

\subsection{Ecological-Political Conditions of Risk Increase in Latin America and the Caribbean}

The politics of risk governance in the Latin American case cannot but consider a political-ecological approach. In that sense, we suggest that the emerging debates on 'neo-extractivism,' hardly addressed within disaster studies, uncover what the political conditions of governance are. That is to say, they foreground how the disaster risk formula 'hazards $x$ exposure $x$ vulnerability' is embedded within the development discourse, the latter operating as a political device of neoliberal governmentality.

Few scholars have addressed disaster studies related to the (neo)extractivism issue. Loperena (2017) has shown an extractivist configuration in the aftermath of Hurricane Mitch in Honduras, at the sight of neoliberal policies underlying the sustainable tourism development discourse. Galvão Lyra (2019) has related disaster governance and mining extractivism to the Fundão dam failure in Brazil in 2015, placing value on the governance model and its political possibility, without explicitly addressing extractivism as a states-engaged regional pattern. In concurrence with our argument, Fernández, Waldmüller, and Vega (2020) explicitly refer to neo-extractivism as being linked to the development model within the 'capitalism of disasters.' They claim that global economic dynamics both produce conditions of vulnerability and truly act as an accelerator of hazards in LAC. Our contribution to this embryonic discussion, then, aims to add how the active role of political factors through state centrality relates to both regional DRG conditions and the intensification of disaster risk factors by using neoextractivism as analytical framework.

A politically heterogeneous panorama developed in LAC as the outcome of a cycle of popular uprisings due to economic crises that hit the region from the end of the last century until the mid-2000s, and demonstrated a legitimacy crisis of the neoliberal agenda (Seoane, Taddei, \& Algranati, 2013). This heterogene- ity enabled the coexistence of different national economic trends, namely: a 'transition' towards socialism in Bolivia, Ecuador, and Venezuela (Ellner, 2014); a progressive, national-populist model, mainly in Argentina, Brazil, and Uruguay (Wylde, 2012); and a conservative model constituted by Mexico, Chile, Peru, Colombia, Paraguay, and most of the Central American countries, whose economic policies implemented during the 1990 s persist, with an emphasis on commercial, financial, and political relations with the United States (López \& Vértiz, 2015).

However, despite the new political picture, social unrest did not subside, not even in left-wing and progressive countries. Social conflicts displaced from the city to the countryside, consequently moving the analysis from a classical capital-labour axis to capital-nature relations (Svampa, 2019). Socio-ecological conflicts emerged, mainly as a result of the devastating environmental effects of economic dynamics (Burchardt \& Dietz, 2014). Such conflict emergence was about the resistance to an actual cartography of activities that indicated a substantial intensification in pressure on territories and natural assets as a direct effect of the accelerated rise in external demand and foreign investment (Jenkins, 2011). This increase in 'social metabolism' was related to the historical and structural unequal terms of ecological exchange in international trade, which have favoured foreign debt and resulted in dependency (Martínez-Alier \& Walter, 2016).

It is worth mentioning some case studies among the largest investments in Latin America, whose activities account for a systematic disaster risk creation by accelerating environmental change, creating new hazards and exposure settings, and thus making the populations more vulnerable: Canadian megamining scattered throughout Peru, Chile, Mexico, Argentina, Brazil, Ecuador, Guatemala, and Honduras has resulted in severe territorial conflicts due to the consequences of ecological predation and human rights violations by this 'imperialist' investor (Gordon \& Webber, 2019). Oil extraction in Ecuador has shown its destructive power, transforming indigenous territory into a kind of 'rainforest Chernobyl' (Cepek, 2012, p. 395). The latter has been illustrative of the scalar mismatch between national benefits and the disastrous local impacts of energy development regarding environmental injustices, which unveils the connections between global lucrative markets and South American gas supplies by hydrocarbon extraction (Perreault, 2018). The forest industry, deployed on a large temporal and spatial scale in Chile as one of its political-economic pillars, radically transformed the socioecological landscape, leading to chronic drought, megafires, multidimensional poverty, and territorial conflicts (Klubock, 2014). Extended agribusiness based on the use of transgenic crops (Barragán-Ocaña, Reyes-Ruiz, Olmos-Peña, \& GómezViquez, 2019) has produced seeds and pesticides with impacts such as genetic contamination of agricultural biodiversity, destruction of natural ecosystems, and 
serious health problems due to the extensive use of pesticides, all with the connivance of local elites and the government (Ruiz-Marrero, 2013). Brazilian leading biofuel production has had the same and other social and unanticipated environmental effects as those generally associated with industrial agriculture (Gordon, 2008). The cross-continental infrastructure plans for communication, transports, and energy have been undertaken by the most aggressive integration project, in favour of transnational flows of the extractive activities: The Initiative for the Integration of Regional Infrastructure in South America (Correa, 2016). This project is an intergovernmental initiative notably suggestive because, while acting as an extractivist pattern booster, it has developed, at the same time, a methodology to incorporate DRM to both prevent or reduce losses associated with extreme events affecting the South American infrastructure and devise plans for connectivity and public infrastructure recovery (South American Council of Infrastructure and Planning, 2016).

All these activities and investments outline the extractive operations in strategic development sectors of the global finance capital. Financialisation, ultimately, organises within this dynamic the logistics of both circulation and pricing, reaching through governmentality even labour and the everyday life of the population, as well as its cooperative forms (Gago \& Mezzadra, 2017, p. 579). Extractivism, then, might be understood as a set of ecological-political operations in the context of the unfolding of financial worldwide capitalism that weaves an extensive and interconnected disaster risk-producing/disaster risk-governance web in its deployment.

\subsection{On the Neo-Extractivism Debate}

Along with the resistance against the deployment of an extractivist matrix over territories, a theoretical discussion sprang from here. This discussion concerned a bundle of issues that, in some way, reproduced regional debates of the 1950s and 1960s concerning LAC's structural peripheral status in the world system and its possibilities to overcome it via modernisation and development (Cardoso \& Faletto, 1979). The implications of a persistently dependent productive structure and the sense of political and economic strategies came into play again, especially in the face of the invocation by the contemporary left-wing and populist progressive governments of a renewed concept of 'national development.' The 'myth' of national development recovered its symbolic efficacy in these political processes (Borón, 2014). However, this time around, rather than promoting industrialisation, internal market, and manufacturing by means of technological innovation the way development discourse once did, all political sectors accepted an extractivist approach to such development. This demonstrated how development "is a concept of monumental emptiness" (Sachs, 2010 , p. X), which can be readily filled with contents at odds.
Due to the increase in the prices of international raw material at the beginning of this century (Jenkins, 2011), and in order to alleviate the recession imposed by the unstable dynamics of the global economy, strengthening the extractive export-oriented models of exploitation became increasingly attractive for all the various governments. This way, a 'commodities consensus' (Svampa, 2015) was established as a discourse of totalising ideological nature, becoming the only and irresistible means to achieving 'progress' and 'national development' (Svampa, 2015).

The term 'neo-extractivism' was originally coined pointing to the left-wing governments of this ecological political model (Gudynas, 2017). Unprecedentedly, in the Latin American left long-standing political tradition, this trend was characterised not just by maintaining the colonialist orientation of economic growth, but also by actively boosting it (Brand, 2013). The state came to play an active role invoking "national development" along with concrete redistribution policies which, in fact, succeeded in the reduction of poverty and inequality rates and improved the quality of living in large sections of the population (Durán Lima, LaFleur, \& Pellandra, 2011). However, there is strong data to claim that despite significant poverty reduction between 2000 and 2012 in most Latin American countries (from $41.7 \%$ to $25.3 \%$ of the regional population), economic vulnerability increased (from $34.4 \%$ to $37.8 \%$; United Nations Development Programme, 2014b). According to the United Nations Development Programme report, this could be explained as the factors associated with poverty reduction not being the same as those associated with people's resilience to adverse economic, personal, and environmental events that may impoverish them. For this reason, national agendas should no longer be limited to neither the achievement of a certain income threshold per capita nor a unique definition of development that is detrimental to the environment (United Nations Development Programme, 2016).

Still, the real novelty rooted in the prefix 'neo' was the regional adherence without exception meant by the consensus. Regardless of the ideological differences of the national governments, the 'commodities consensus' deepened the expansive dynamics of dispossession of global capitalism (Harvey, 2004) embodied in processes of land grabbing, state-led relocations, destruction of territories, and displacement of populations "principally by large corporations, in multiscalar alliances with different governments" (Raju, 2013; Svampa, 2015, p. 66). In other words, it was about the creation of unsafe conditions and vulnerability through political-economic arrangements led by national states.

Entangled in this framework, the development idea showed its environmental destructive effects. In turn, its political scope was unveiled as a set of discourses and practices, both with a substantial impact on understanding LAC as a region of 'developing' countries useful for a neo-colonial enterprise worldwide (Esteva \& 
Escobar, 2017). It is nowadays well demonstrated that, despite the progressive idea of 'development with inclusion' in LAC, it did not contribute to delay nor to overcome a delegitimised ongoing neoliberalism. On the contrary, it resulted in a discursive 'fantasy' whose actual counterpart was the continuity of the neoliberal societal matrix (Machado Aráoz \& Lisdero, 2019). The relationship between development, neoliberalism, and the construction of vulnerability and disaster risk of large segments of societies (Oliver-Smith, 2015, p. 46) embodied in LAC as a paradigmatic example.

The political-economic model that was set up since the early 2000s, consequently, implied the engagement of several multi-leveled actors of different interests and unequal range of actions, influence and capacities. Just like the risk governance model, this one constituted a multiscale structural dynamic of socio-spatial relationships that brought together global, national, and local interests (Svampa, 2015); here around localised extractive activities acting as risk factor intensifiers outlined above. Spread across the region, these activities represent not just a ubiquitous phenomenon, but also a relational, omnipresent, and temporal one (Martín, 2017, p. 35). As explained earlier, this multiscalar dynamic has been one of the expressions of neoliberal governance in LAC that allocated a 'meta-regulatory' role to the state (De Sousa Santos, 2005). The retraction of the state from social regulations created the space for "legitimate nonstate self-regulators" (De Sousa Santos, 2009, p. 51), and the state itself was relegated to participate as a 'partner' on equal terms, although it remained influential. This historical realignment sought, indeed, to guarantee the institutionalisation of rights for large corporations in accordance with guidelines established in transnational spaces. The results have been a sort of 'institutionalised risks' and weak legislative policy in which financial private interests prevail to the detriment of other social groups. In fact, regulatory statutes have been managed in collaboration with the very part regulated, this latter strongly connected to transnational capital (Córdoba, Chiappe, Abrams, \& Selfa, 2018).

There is strong evidence to sustain that the powerful have 'specific disincentives' from the states to reduce risk, particularly in 'developing countries,' which have been most attractive for investment as "the current state of affairs is beneficial for them" (Keating et al., 2017, p. 74). This has exacerbated the vulnerability and, thus, disaster risks of local communities whose rights have been breached by influential global agents, to the extent that the decision field has been set up beyond the terms disputed locally. Therefore, the problem of neoextractivism turns out to be paradigmatic insomuch as it allows the observation, within its multiscalar dynamic, of the links between the social production of disaster risk, the economic-political agreements at a regional level that feed the production of risks at local level, and the DRG policies on disaster risk. The commitment of national governments with DRG will not be more than a statement of goodwill if they remain subordinated to the extractivist regional primirising pattern.

\section{Conclusions}

Gathering literature from three different discussion scenes (the social construction of disaster risk, DRG, and the ecological-political processes at the regional level in LAC) has allowed us to observe the 'double bind' in DRG policy through the problem of neo-extractivism as an analytical device. It is a fact that global social, political, and economic processes are leading to a proliferation of disasters deeply intertwined with the hegemonic understanding of development (Oliver-Smith et al., 2017). That view of development is directly related to the Latin American neo-extractivism debate, which has raised many questions about development issues itself. Hence, we have proposed the critical lens of 'neoextractivism' as a way of understanding DRG.

There is a clear correlation between the contemporary sociopolitical processes in LAC and the environmental degradation that brings about disasters triggered by political arrangements and decisions. The dynamic relationships between society and nature have become a challenge that is to be understood in light of the social construction of disasters, also considering "the complex temporalities-incremental, slow, and multi-scalar-at play" (Tironi et al., 2019, p. 193). That is to say, long and slow processes which, in fact, are producing much more deaths and losses across time than is generally estimated (Knowles, 2014).

Drawing on 'neo-extractivism' discussion helps to better understand the vulnerability approaches, foregrounding the 'reproductive crisis' of life that generates disasters mostly due to structural conditions (Fernández et al., 2020, p. 11). Power relations and practices are producing socio-natural hazards, and, thus, different forms of vulnerability in LAC, from 'neo-extractivism' as an economic, political, cultural, and historical matrix that is territorially organised. Hence, disasters are matters of human rights (Raju \& da Costa, 2018) and DRR must encompass a discussion on vulnerability and human rights. LAC is one of the places of the world where permanent vulnerability to hazards is actively created by the legacies of colonisation, the post-colonial political and economic order, controlled from inside and outside as a function of capitalist accumulation.

In sum, neo-extractivism appears to be an analytical device to understand the systemic production of disaster risk and the political conditions of DRG in LAC. It displays the problematic performance of a sociopolitical, temporal, and spatial model enabling to contrast and problematise elements of the different levels of the DRG architecture and the links among them, mainly in relation to regional DRG. In this article, the political-ecological dynamic of 'neo-extractivism' is shown as the other real side of regional DRG possibilities; i.e, the actual embodiment of its descriptive architecture. In other words, it is 
what is actually being done behind the ideal normative guidelines and governmental commitments. The formal commitments of national governments with DRM have no effect on DRR to the extent that, at the same time, a regional extractive pattern producing disasters and disaster risks continues to be promoted at the local level. To unearth this contributes to set out the limitations of dominant approaches to disaster governance, framed around a set of myths and 'blind spots' which are part of a broader ideological framework based on power dynamics (Delabre et al., 2020).

Last but not least, there is a relationship between this reproductive crisis and the very concept of the 'politics.' The conventional political understanding that still takes for granted the state as a key piece in risk governance makes use of the same conceptual pivot of 'politics' as the structural dynamic that produces vulnerability and unsafe conditions. Both dimensions-political and structural-in turn have drawn on the development imaginary and practices for governing purposes, in a functional way with the disastrous deployment of neoliberalism in the region. That is why the questioning of conceptual underpinnings might be an endless but nonetheless necessary aim for the relevance of the future of disaster studies and its transformation.

\section{Acknowledgments}

Andrés Pereira acknowledges research support for this publication from the Copenhagen Center for Disaster Research (COPE), University of Copenhagen, the National Agency for Research and Development (ANID-Chile)/ Scholarship Program/DOCTORADO NACIONAL/201621161172, and Fondecyt No. 1190528.

\section{Conflict of Interests}

The authors declare no conflict of interests.

\section{References}

Alcántara-Ayala, I. (2019). Time in a bottle: Challenges to disaster studies in Latin America and the Caribbean. Disasters, 43(1), 18-27.

Aven, T., \& Renn, O. (2010). Risk management and governance: Concepts, guidelines and applications. London and New York, NY: Springer.

Aysan, Y., \& Lavell, A. (2014). Disaster risk governance during the hfa implementation period. New York, NY: United Nations World Conference on Disaster Risk Reduction.

Barragán-Ocaña, A., Reyes-Ruiz, G., Olmos-Peña, S., \& Gómez-Viquez, H. (2019). Production, commercialization, and intellectual property of transgenic crops in Latin America: A state of the art review. Journal of Agribusiness in Developing and Emerging Economies, 9(4), 333-351.

Bassols, M. (2011). Gobernanza: Una mirada desde el poder [Governance: A view from power]. In M. Bassols \& C. Mendoza (Eds.), Gobernanza: Teoría y prácticas colectivas [Governance: Theory and collective practices] (pp. 7-35). Mexico City: Anthropos.

Benson, D., \& Jordan, A. (2017). Environmental governance. International Encyclopedia of Geography. https://doi.org/10.1002/9781118786352.wbieg0631

Borgo, R. L. (2016). About disaster risk governance in the Americas and the Sendai DRR Framework 2015-2030. Unpublished manuscript.

Borón, A. (2014). Twenty-first century socialism: Is there life after neoliberalism? Canada: Fernwood Publishing.

Brand, U. (2013). The role of the state and public policies in processes of transformation. In M. Lang \& D. Mokrani (Eds.), Beyond development: Alternative visions from Latin America (pp. 105-116). Amsterdam: Transnational Institute and Rosa Luxemburg Foundation.

Burchardt, H.-J., \& Dietz, K. (2014). (Neo-)extractivism: A new challenge for development theory from Latin America. Third World Quarterly, 35(3), 468-486.

Cardona, O. D., Bertoni, J. C., Gibbs, T., Hermelin, M., \& Lavell, A. (2010). Understanding and managing risk associated with natural hazards: An integrated scientific approach in Latin America and the Caribbean. Rio de Janeiro and Mexico City: ICSU-LAC and CONACYT.

Cardoso, F. H., \& Faletto, E. (1979). Dependency and development in Latin America. Berkeley, CA: University of California Press.

Castel, R. (1991). From dangerousness to risk. In G. Burchell, C. Gordon, \& P. Miller (Eds.), The Foucault effect: Studies in governmentality (pp. 281-298). Chicago, IL: The University of Chicago Press.

Cepek, M. (2012). The Loss of oil: Constituting disaster in Amazonian Ecuador. The Journal of Latin American and Caribbean Anthropology, 17(3), 393-412.

Córdoba, D., Chiappe, M., Abrams, J., \& Selfa, T. (2018). Fuelling social inclusion? Neo-extractivism, statesociety relations and biofuel policies in Latin America's southern cone. Development and Change, 49(1), 63-88.

Correa, F. (2016). Beyond the city: Resource extraction urbanism in South America. Austin, TX: University of Texas Press.

Cuny, F. C. (1983). Disasters and development. New York, NY: Oxford University Press.

De Sousa Santos, B. (2005). Beyond neoliberal governance: The World Social Forum as subaltern cosmopolitan politics and legality. In B. De Sousa Santos \& C. A. Rodríguez Garavito (Eds.), Law and globalization from below: Towards a cosmopolitan legality (pp. 29-63). Cambridge: Cambridge University Press.

De Sousa Santos, B. (2009). Governance: Between myth and reality. RCCS Annual Review: A Selection from the Portuguese Journal Revista Crítica de Ciências Sociais. https://doi.org/10.4000/rccsar.95 
Dean, M. (2010). Governmentality: Power and rule in modern society (2nd ed.). London: SAGE.

Delabre, I., Boyd, E., Brockhaus, M., Carton, W., Krause, T., Newell, P., . . . Zelli, F. (2020). Unearthing the myths of global sustainable forest governance. Global Sustainability, 3(16), 1-10.

Durán Lima, J., LaFleur, M., \& Pellandra, A. (Eds.). (2011). Trade, poverty and complementary policies in Latin America. Santiago: Economic Commission for Latin America and the Caribbean.

Ellner, S. (Ed.). (2014). Latin America's radical Left: Challenges and complexities of political power in the twenty-first Century. Lanham, MD: Rowman \& Littlefield.

Esteva, G., \& Escobar, A. (2017). Post-development @ 25: On 'being stuck' and moving forward, sideways, backward and otherwise. Third World Quarterly, 38(12), 2559-2572.

Ferguson, J., \& Gupta, A. (2002). Spatializing states: Toward an ethnography of neoliberal governmentality. American Ethnologist, 29(4), 981-1002.

Fernández, A. G., Waldmüller, J., \& Vega, C. (2020). Comunidad, vulnerabilidad y reproducción en condiciones de desastre: Abordajes desde América Latina y el Caribe [Community, vulnerability and reproduction in disaster conditions: Approaches from Latin America and the Caribbean]. Íconos: Revista de Ciencias Sociales, 66, 7-29.

Flyvbjerg, B., \& Richardson, T. (2005). Planning and Foucault: In search of the dark side of planning theory. In P. Allmendinger \& M. Tewdwr-Jones (Eds.), Planning futures: New directions for planning theory (pp. 44-62). New York, NY: Routledge.

Foucault, M. (2009). Security, territory, population: Lectures at the Collège De France, 1977-1978. New York, NY: Palgrave Macmillan.

Fraser, N. (2003). From discipline to flexibilization? Rereading Foucault in the shadow of globalization. Constellations, 10(2), 160-171.

Frenkel, A. (2019). "Shoot against the waves": Securitization and militarization of natural disasters and humanitarian help in Latin America. Íconos: Revista de Ciencias Sociales, 64, 183-202.

Gago, V., \& Mezzadra, S. (2017). A critique of the extractive operations of capital: Toward an expanded concept of extractivism. Rethinking Marxism, 29(4), 574-591.

Gall, M., Cutter, S. L., \& Nguyen, K. H. (2014). Governance in disaster risk management (IRDR AIRDR Publication No. 3). Beijing: Integrated Research on Disaster Risk.

Galvão Lyra, M. (2019). Challenging extractivism: Activism over the aftermath of the Fundão disaster. The Extractive Industries and Society, 6(3), 897-905.

García Acosta, V. (1996). Historia y desastres en América Latina [History and disasters in Latin America]. Mexico City: Centro de Investigaciones y Estudios Superiores en Antropología Social and Red de Estu- dios Sociales en Prevención de Desastres en América Latina.

García Acosta, V. (2018). Vulnerabilidad y desastres: Génesis y alcances de una visión alternativa [Vulnerability and disasters: Genesis and scope of an alternative visión]. In M. González de la Rocha \& G. A. Saraví (Eds.), Pobreza y vulnerabilidad: Debates y estudios contemporáneos en México [Poverty and vulnerability: Contemporary debates and studies in Mexico] (pp. 212-239). Mexico City: Centro de Investigaciones y Estudios Superiores en Antropología Social.

González, S. G. (2015). Prohibido hablar de vulnerabilidad [Forbidden to talk about vulnerability]. Nexorrd. Retrieved from https://www.nexorrd.org/ single-post/2015/07/08/PROHIBIDO-HABLAR-DEVULNERABILIDAD

González Casanova, P. (Ed.). (1990). El Estado en América Latina: Teoría y práctica [The state in Latin America: Theory and practice]. Mexico City: Siglo XXI.

Gordon, G. (2008). Biofuels: Fueling development or disaster? Berkeley, CA: Center for Latin America Studies. Retrieved from https://clas.berkeley.edu/sites/ default/files/shared/docs/tertiary/2008FallBRLASTinker-GretchenArticle.pdf

Gordon, T., \& Webber, J. R. (2019). Canadian capital and secondary imperialism in Latin America. Canadian Foreign Policy Journal, 25(1), 72-89.

Gudynas, E. (2013). Debates on development and its alternatives in Latin America. A brief heterodox guide. In M. Lang \& D. Mokrani (Eds.), Beyond development: Alternative visions from Latin America (pp. 15-39). Amsterdam: Transnational Institute and Rosa Luxemburg Foundation.

Gudynas, E. (2017). Extractivisms: Tendencies and consequences. In R. Munck \& H. Veltmeyer (Eds.), Alternative Development models: Latin American results and prospects (pp. 61-76). London: Routledge.

Guerrero Compeán, R., Salazar, L., \& Lacambra Ayuso, S. (2017). Gestionando el riesgo: Efectos de la gobernabilidad en las pérdidas humanas por desastres en América Latina y el Caribe [Managing risk: Effects of governability on human losses from disasters in Latin America and the Caribbean] (IDB-WP-819). Washington, DC: Inter-American Development Bank.

Harvey, D. (2004). The 'new' imperialism: Accumulation by dispossession. Socialist Register, 40 . https://socialistregister.com/index.php/srv/article/ view/5811

Harvey, D. (2005). A brief history of neoliberalism. New York, NY: Oxford University Press.

Hewitt, K. (1983). Interpretations of calamity: From the viewpoint of human ecology. London: Allen \& Unwin.

Hollis, S. (2015). The role of regional organizations in disaster risk management: A strategy for global resilience. New York, NY: Palgrave Macmillan.

Hufty, M. (2009). Una propuesta para concretar el concepto de gobernanza: El marco analítico de la gober- 
nanza [A proposal for concretizing the concept of governance: The governance analytical framework]. In $\mathrm{H}$. Mazurek (Ed.), Gobernabilidad y gobernanza de los territorios en América Latina [Governability and governance of territories in Latin America] (pp. 77-100). Lima: Instituto Francés de Estudios Andinos.

Hufty, M. (2011). Investigating policy processes: The governance analytical framework (GAF). In U. Wiesmann \& H. Hurni (Eds.), Research for sustainable development: Foundations, experiences, and perspectives (pp. 403-424). Switzerland: Geographica Bernensia.

Jenkins, R. O. (2011). The 'China effect' on commodity prices and Latin American export earnings. CEPAL Review, 103, 73-87.

Jordan, A. (2008). The governance of sustainable development: Taking stock and looking forwards. Environment and Planning C: Government and Policy. https://doi.org/10.1068/cav6

Keating, A., Campbell, K., Mechler, R., Magnuszewski, P., Mochizuki, J., Liu, W., . . McQuistan, C. (2017). Disaster resilience: What it is and how it can engender a meaningful change in development policy. Development Policy Review, 35(1), 65-91.

Klubock, T. M. (2014). La frontera: Forests and ecological conflict in Chile's frontier territory. Durham, NC: Duke University Press.

Knowles, S. G. (2014). Learning from disaster? The history of technology and the future of disaster research. Technology and Culture, 55(4), 773-784.

Lavell, A., Gaillard, J. C., Wisner, B., Saunders, W., \& van Niekerk, D. (2012). National planning and disaster. In B. Wisner, J. C. Gaillard, \& I. Kelman (Eds.), Handbook of hazards and disaster risk reduction (pp. 617-628). New York, NY: Routledge.

Loperena, C. A. (2017). Honduras is open for business: Extractivist tourism as sustainable development in the wake of disaster? Journal of Sustainable Tourism, 25(5), 618-633.

López, E., \& Vértiz, F. (2015). Extractivism, transnational capital, and subaltern struggles in Latin America. Latin American Perspectives, 42(5), 152-168.

Machado Aráoz, H., \& Lisdero, P. (2019). Neoliberalization and new commodification frontiers: A global critique of progressive reason. In A. Scribano, F. Timmermann Lopez, \& M. E. Korstanje (Eds.), Neoliberalism in multi-disciplinary perspective (pp. 45-65). Cham: Palgrave Macmillan.

Martín, F. (2017). Reimagining extractivism: Insights from spatial theory. In B. Engels \& K. Dietz (Eds.), Contested extractivism, society and the state: Struggles over mining and land (pp. 21-44). London: Palgrave Macmillan.

Martínez-Alier, J., \& Walter, M. (2016). Social metabolism and conflicts over extractivism. In F. de Castro, B. Hogenboom, \& M. Baud (Eds.), Environmental governance in Latin America (pp. 58-85). London: Palgrave Macmillan.

Middleton, N., \& O'Keefe, P. (1998). Disaster and devel- opment: The politics of humanitarian aid. London: Pluto Press.

O’Keefe, P., Westgate, K., \& Wisner, B. (1976). Taking the naturalness out of natural disasters. Nature, 260, 566-567.

Oliver-Smith, A. (2004). Theorizing vulnerability in a globalized world: A political ecological perspective. In G. Bankoff, G. Frerks, \& D. Hilhorst (Eds.), Mapping vulnerability: Disasters, development, and people (pp. 10-24). London: Earthscan.

Oliver-Smith, A. (2015). Conversations in catastrophe: Neoliberalism and the cultural construction of disaster risk. In F. Krüger, G. Bankoff, T. Cannon, B. Orlowski, \& E. L. F. Schipper (Eds.), Cultures and disasters: Understanding cultural framings in disaster risk reduction (pp. 37-52). London and New York, NY: Routledge.

Oliver-Smith, A. (2017). Adaptation, vulnerability, and resilience: Contested concepts in the anthropology of climate change. In H. Kopnina \& E. ShoremanOuimet (Eds.), Routledge handbook of environmental anthropology (pp. 206-218). New York, NY: Routledge.

Oliver-Smith, A., Alcántara-Ayala, I., Burton, I., \& Lavell, A. (2016). Forensic investigations of disasters (FORIN): A conceptual framework and guide to research. Beijing: Integrated Research on Disaster Risk.

Oliver-Smith, A., Alcántara-Ayala, I., Burton, I., \& Lavell, A. (2017). The social construction of disaster risk: Seeking root causes. International Journal of Disaster Risk Reduction, 22, 469-474.

Pelling, M., \& Dill, K. (2010). Disaster politics: Tipping points for change in the adaptation of sociopolitical regimes. Progress in Human Geography, 34(1), 21-37.

Perreault, T. (2018). Energy, extractivism and hydrocarbon geographies in contemporary Latin America. Journal of Latin American Geography, 17(3), 235-252.

Quijano, A. (2000). Coloniality of power and eurocentrism in Latin America. International Sociology, 15(2), 215-232.

Raju, E. (2013). Housing reconstruction in disaster recovery: A study of fishing communities posttsunami in chennai, India. PLoS Currents, 5. https:// doi.org/10.1371/currents.dis.a4f34a96cb91aaffacd $36 \mathrm{f} 5 \mathrm{ce} 7476 \mathrm{a} 36$

Raju, E., \& da Costa, K. (2018). Governance in the Sendai: A way ahead? Disaster Prevention and Management: An International Journal, 27(3), 278-291.

Renn, O. (2008). Risk governance: Coping with uncertainty in a complex world. Abingdon: Earthscan.

Rentschler, J. E. (2013). Why resilience matters: The poverty impacts of disasters (Policy Research Working Paper 6699). Washington DC: The World Bank.

Rojas, C., \& Kindornay, S. (2014). The politics of governing development. In H. Weber (Ed.), The politics of development: A survey. London: Routledge. 
Ruiz-Marrero, C. (2013). Latin America: The tragedy of genetically modified crops and the promise of agroecology. Alainet. Retrieved from https://www.alainet. org/en/articulo/79676

Sachs, W. (Ed.). (2010). The development dictionary: A guide to knowledge as power (2nd ed.). London and New York, NY: Zed Books Ltd.

Sandoval, V., \& Sarmiento, J. P. (2019). A neglected issue: Informal settlements, urban development, and disaster risk reduction in Latin America and the Caribbean (Contributing Paper to the UNDRR Global Assessment Report on Disaster Risk Reduction). Geneva: United Nations Office for Disaster Risk Reduction.

Sandoval, V., \& Voss, M. (2016). Disaster governance and vulnerability: The case of Chile. Politics and Governance, 4(4), 107-116.

Seoane, J., Taddei, E., \& Algranati, C. (2013). Extractivismo, despojo y crisis climática: Desafíos para los movimientos sociales y los proyectos emancipatorios de nuestra América [Extractivism, dispossession and the climate crisis: Challenges for social movements and emancipatory projects in our America]. Buenos Aires: Ediciones Herramienta, Editorial El Colectivo and GEAL.

Shinbrot, X. A., Jones, K. W., Rivera-Castañeda, A., LópezBáez, W., \& Ojima, D. S. (2019). Smallholder farmer adoption of climate-related adaptation strategies: The importance of vulnerability context, livelihood assets, and climate perceptions. Environmental Management, 63(5), 583-595.

South American Council of Infrastructure and Planning. (2016). La gestión de riesgos de desastres en COSIPLAN: Metodología y aplicación en infraestructura de Chile y Peru [Disaster risk management in COSIPLAN: Methodology and application to Chilean and Peruvian infrastructure]. Buenos Aires: COSIPLAN.

Svampa, M. (2015). Commodities consensus: Neoextractivism and enclosure of the commons in Latin America. South Atlantic Quarterly, 114(1), 65-82.

Svampa, M. (2019). Neo-extractivism in Latin America: Socio-environmental conflicts, the territorial turn, and new political narratives. Cambridge: Cambridge University Press.

Svampa, M., \& Viale, E. (2014). Maldesarrollo: La Argentina del extractivismo y el despojo [Bad development: Extractivist Argentina and dispossession]. Buenos Aires: Katz.

Thompson, D. D. P. (2020). Disaster risk governance: Four cases from developing countries. New York, NY and London: Routledge.

Tierney, K. (2012). Disaster governance: Social, political, and economic dimensions. Annual Review of Environment and Resources, 37(1), 341-363.

Tironi, M., Bacigalupe, G., Knowles, S. G., Dickinson, S., Gil, M., Kelly, S., . . . Waldmueller, J. (2019). Figuring disasters, an experiment on thinking disruptions as methods. Resilience, 7(2), 192-211.

United Nations Development Programme. (2014a). What does United Nations Development Programme do in disaster risk reduction in Latin America and the Caribbean? United Nations Development Programme. Retrieved from https://issuu.com/ cprundprsclac/docs/desastres_bro_eng

United Nations Development Programme. (2014b). Perfil de estratos sociales en América Latina: Pobres, vulnerables y clases medias [Profile of social groups in Latin America: The poor, the vulnerable and the middle class]. New York, NY: United Nations Development Programme. Retrieved from https:// www.lampadia.com/assets/uploads_documentos/ 8975e-docs27082014.pdf

United Nations Development Programme. (2016). Progreso multidimensional: Bienestar más allá del ingreso: Informe Regional sobre Desarrollo Humano para América Latina y el Caribe [Multidimensional progress: Well-being beyond income: Regional Human Development Report for Latin America and the Caribbean]. New York, NY: United Nations Development Programme.

United Nations Office for Disaster Risk Reduction. (2015a). Global assessment report on disaster risk reduction 2015: Making development sustainable: The future of disaster risk management. Geneva: United Nations.

United Nations Office for Disaster Risk Reduction. (2015b). Sendai Framework for Disaster Risk Reduction 2015-2030. Geneva: United Nations.

United Nations Office for Disaster Risk Reduction. (2017a). 2017 global platform for disaster risk reduction. proceedings. Geneva: United Nations.

United Nations Office for Disaster Risk Reduction. (2017b). Plan de acción regional para la implementación del Marco de Sendai para la Reducción del Riesgo de Desastres 2015-2030 en las Américas [Regional action plan for the implementation of the Sendai Framework for Disaster Risk Reduction 2015-2030 in the Americas]. Geneva: United Nations.

Wallemacq, P., \& House, R. (2018). Economic losses, poverty \& disasters: 1998-2017. Geneva: Centre for Research on the Epidemiology of Disasters.

Watanabe, M. (2013). Institutionalising disaster risk management: Latin America's systems approach. Lima: Evidence and Lessons from Latin America.

Wilches-Chaux, G. (1993). La vulnerabilidad global [Global vulnerability]. In A. Maskrey (Ed.), Los desastres no son naturales [Disasters are not natural] (pp. 11-44). Lima, Peru: Red de Estudios Sociales en Prevención de Desastres en América Latina.

Wisner, B., Blaikie, P., Cannon, T., \& Davis, I. (1994). At risk: Natural hazards, people's vulnerability and disasters. London and New York, NY: Routledge.

World Bank. (2012). Disaster risk management in Latin America and the Caribbean Region: GFDRR country notes. Washington DC: The World Bank.

Wylde, C. (2012). Latin America after neoliberalism: Developmental regimes in post-crisis states. New York, NY: Palgrave Macmillan. 


\section{About the Authors}

Andrés Pereira is currently associated with the research group on 'Disaster Cultures and Risk Governance' at the Research Center for Integrated Disaster Risk Management (CIGIDEN), ANID/FONDAP/15110017, while finalising a PhD in Political Philosophy at University of Chile. He holds a PhD in Social Sciences and a Master's degree in Interdisciplinary Studies of Subjectivity from University of Buenos Aires. His research interests include disaster risk studies, subjectivities, political ecology, Latin American studies, and contemporary social and political thought.

Emmanuel Raju is an Associate Professor at the Global Health Section, University of Copenhagen, and currently directs the Copenhagen Centre for Disaster Research. He is the Co-Editor of the Disaster Prevention and Management Journal. He is also an Extraordinary Associate Professor at the African Centre for Disaster Studies, South Africa. His research interests include disaster risk reduction, governance, climate change adaptation and development. 